\title{
PartyPolitics
}

\section{Socio-economic voter profile and motives for Islamist support in Morocco}

\author{
Miquel Pellicer and Eva Wegner
}

University of Cape Town, South Africa

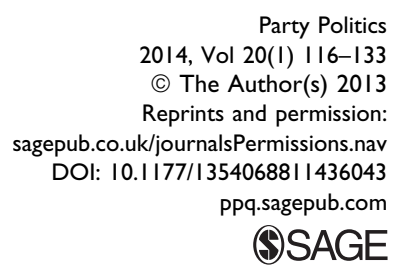

2014, Vol 20(I) 116-133

(C) The Author(s) 2013

Reprints and permission: (1)

@SAGE

\begin{abstract}
Based on an original dataset of merged electoral and census data, this article is a study of electoral support for the Islamist Party in Morocco in the 2002 and 2007 elections. It differentiates between the clientelistic, grievance and horizontal network type of supporters. We disentangle these profiles empirically on the basis of the role of education, wealth and exclusion for Islamist votes. We find no evidence of the clientelistic profile, but a shift from grievance in 2002 to a horizontal network profile in 2007. World Values Survey individual level data are used as a robustness check, yielding similar results. Qualitative evidence on a changing mobilization pattern of the party between 2002 and 2007 supports our conclusions.
\end{abstract}

\section{Keywords}

elections, Islamist parties, Middle East and North Africa, Morocco, opposition

\section{Introduction}

The nature of Islamist political parties is at the core of debates about the political future of the Middle East and North Africa (MENA). The relevance of these debates has increased as strong popular pressure for democratization has ousted some MENA regimes and brought others to enact political reforms. Indeed, Islamist parties are the likely beneficiaries of such reforms. Yet, little is known about the sources behind the strength of Islamist political parties. Who votes for Islamist parties and why? To which electorate do Islamist parties respond? In fact, there have been as many surprise victories as surprise failures of Islamist parties in recent years. For lack of data on Islamist voters, most explanations offered are directly drawn from studies on Islamist movement organizations, such as the Muslim Brotherhoods in Egypt and Jordan. Movement organizations and parties, however, are two different entities; they operate in different spheres, they obey different logics, and, over time, they might develop different objectives (Wegner, 2011; Wegner and Pellicer, 2009). Similarly, activists - whether of the party or the movement organizations - are different from a larger pool of sympathizers: sympathizers are receptive to the ideas of the party or movement but are not sufficiently mobilized to engage directly in political action. In short, it is a long way from the profile of an activist inside an Islamist movement organization to one of a voter of an Islamist party.
To date, there are only two studies on Islamist voters based on survey data, which, however, tend to reach different conclusions. Garcia-Rivero and Kotze (2007) base their analysis on the World Values Survey (WVS) for Morocco, Algeria, Jordan and Turkey. Robbins (2009) draws on survey data from the Arab Barometer for Morocco, Algeria, Jordan, Yemen and the West Bank and Gaza. In both studies, the only variable that is significant in all countries is that religion should play a greater role in politics - a rather tautological result given that this is part of the core identity of Islamist parties. Beyond that, the results usually differ for the same country and across countries (for Jordan, for instance, dissatisfaction with the state/government, for instance, is highly significant in Robbins (2009) but irrelevant in Garcia-Rivero and Kotze (2007)). The discrepancies between these studies may partly be due to small samples of supporters of the respective Islamist party. ${ }^{1}$ Additionally, in authoritarian settings, survey information regarding politics has to be treated with care, as people might not feel comfortable giving information about their

Paper submitted 04 March 20I I; accepted for publication 22 May 20II

\section{Corresponding author:}

Eva Wegner, SALDRU, University of Cape Town, Private Bag X3, Rondebosch, 770I, South Africa.

Email: wegner.eva@gmail.com 
political opinions to strangers. Support for Islamist parties could be under-reported, as many Islamist groups are illegal or have an ambiguous legal status, and even legal Islamist parties and groups are often harassed by the regimes. At the same time, overestimating of support has also occurred. In Morocco, a 2006 poll attributed 47 percent vote intention for the Islamists compared to around 3 percent of registered voters who voted for the party one year later, ${ }^{2}$ also, overestimating occurs in the 2007 WVS for Morocco, although less extreme. ${ }^{3}$

This article complements the emerging literature on Islamist voters in a study of the electoral support for the Moroccan Party of Justice and Development (PJD) in 2002 and 2007 based on an original dataset of merged electoral and census data. We derive stylized profiles of Islamist supporters from the literature on Islamic activism, differentiating between clientelistic, grievance and horizontal network types of supporters. These potential voters differ in their degree of education, wealth and inclusion and have different demands and expectations vis-à-vis the Islamist party. We propose distinguishing between clientelistic and the other profiles on the basis of the role of education: if support is driven by clientelism, PJD votes should be negatively related to education levels. We distinguish between grievance and horizontal network profiles on the basis of wealth and inclusion, conditional on education: if the dominant pattern of support is based on grievances, PJD votes should be associated with relative poverty and exclusion for a given level of education. The opposite would apply in the case of a horizontal network profile.

We find a strong positive relation between education and PJD votes in the two years, thus concluding that support for Moroccan Islamists was not driven by a clientelistic rationale in either of the two elections. However, we find an important difference between 2002 and 2007 regarding the role of wealth and inclusion conditional on education, turning from negative to positive. Thus we conclude that in 2002 the pattern of support was close to a grievance type of profile but changed in 2007 to resemble more closely the horizontal network type.

Our analysis potentially suffers from limitations of its own, notably the risk of ecological fallacy. Our inferences on PJD support are necessarily based on differences in averages of districts, not on differences among individuals. In our case, the risk is a priori important because the districts in our data are relatively large $(300,000$ inhabitants on average). However, spatial inequalities in Morocco are such that they yield what we believe is sufficient heterogeneity across districts in our key variables (literacy, for example, ranges almost uniformly from as little as 30 to 80 percent across districts). To address the possibility of ecological fallacy, we perform the same type of analysis using individual data from the WVS on intended PJD support in 2001/2002 and 2007. The results from this analysis are remarkably in line with our previous one regarding the relation between individual PJD support intention and our indicators of education and wealth.

Finally, we discuss qualitative evidence on a changing mobilization pattern of the PJD, which evolved from a pronounced opposition profile to a rather tame, technocratic one, a trajectory consistent with our quantitative analyses. Overall, our findings suggest that the electorate of Islamist parties is not composed of a stable support base of committed ideologues, but varies according to the party's mobilization decisions.

Section 2 derives the profiles of Islamist supporters. Section 3 provides a brief background of Moroccan politics. Section 4 describes the data. Sections 5 and 6 present the findings on electoral support for the Moroccan Islamist party in 2002 and 2007, discussing commonalities and differences respectively. Section 7 concludes.

\section{Profiles of Islamist supporters}

The literature on Islamic activism provides a variety of answers to the question of who supports Islamist groups and why. As mentioned, few studies have used survey data and looked specifically at support for Islamist parties - as opposed to Islamist movement organizations. Given the dearth of studies focusing on Islamist parties specifically, we draw on both party and movement studies to establish ideal types of Islamist supporters. For our purpose, we systematize, unify and simplify answers provided by these studies in order to derive profiles that are stylized and can be operationalized to guide the subsequent analysis. Our reading of the literature yields three types of profile with different socio-economic and political characteristics and expectations towards the Islamist party: (a) a clientelist profile, (b) a grievance-driven profile, and (c) a horizontal network profile of Islamist support. An overview of these profiles is given in Table $1 .^{4}$

The clientelist and grievance profiles are probably the most common reasons cited for individuals supporting Islamists groups, passively or actively. The clientelist profile of an Islamist activist or supporter is generally placed in the context of the inability of Arab states to provide public goods and employment for their citizens. Islamist groups have stepped in to provide education, hospitals, jobs, clothing, low cost credit, etc., to the poor. These charitable activities are thought to be 'networks of patronage and clientship" (Zubaida, 1992: 9) where recipients of benefits become supporters in exchange (see Fuller, 2003; Layachi and Haireche, 1992; Roussillon, 1991). ${ }^{5}$ As Toth puts it, the poor 'gratefully appreciated' these services, whereas the Islamists benefited from 'the allegiance they won from doing their good deeds' (2003: 559), and when Islamists entered electoral contests they 'received overwhelming support and loyalty from those they had once assisted" (ibid.). Thus, a patron-client relationship is formed in 
Table I. Profiles of potential Islamist voters.

\begin{tabular}{lllll}
\hline Profile & Characteristics & $\begin{array}{c}\text { Expectations from } \\
\text { Islamist Party (IP) }\end{array}$ & Operationalization & Inference \\
\hline Clientelism & Poor, vulnerable & Patronage & $\begin{array}{c}\text { Low education } \\
\text { Poor Excluded } \\
\text { High education } \\
\text { Poor and excluded } \\
\text { relative to education }\end{array}$ & $\begin{array}{c}\text { IP results better in low education } \\
\text { districts }\end{array}$ \\
$\begin{array}{c}\text { Horizontal } \\
\text { network }\end{array}$ & $\begin{array}{c}\text { Frustrated } \\
\text { aspirations }\end{array}$ & Radical change & $\begin{array}{c}\text { Conditional on education, better in } \\
\text { poorer and excluded districts }\end{array}$ \\
(professionals) & $\begin{array}{c}\text { Moderate change } \\
\text { (policies) }\end{array}$ & $\begin{array}{c}\text { Medium wealth } \\
\text { Medium exclusion }\end{array}$ & $\begin{array}{c}\text { IP better in high education districts } \\
\text { Conditional on education, unrelated } \\
\text { to wealth and exclusion }\end{array}$ \\
\hline
\end{tabular}

which the Islamists help out poor, uneducated, vulnerable and excluded individuals, and the latter support them. In elections, such a clientelist voter would not ask for specific policies or more substantial political change, she would simply reward services provided by the Islamists in the past or future with her vote.

The grievance-driven supporter profile is also placed in the context of economic development failure of MENA regimes. In contrast to the clientelist profile, however, these grievances are mainly seen as relative deprivation suffered by recently educated MENA citizens. Lacking employment opportunities, the unfulfilled aspirations of potentially upwardly mobile individuals transform into a demand for change (see, among many others, Carvalho (2009), Woltering (2002), Nachtwey and Tessler (1999) and Tessler (1997); see Wiktorowicz (2004) for a survey of this work). ${ }^{6}$ Such change, in turn, is being promised most convincingly by Islamist groups, the only sizeable opposition in the MENA. It is thus a fact that Islamist parties are the most promising and credible opposition to the status quo that would account for Islamist party support (Garcia Rivero and Kotze, 2007). The grievance profile that emerges from this literature is thus that of an individual with few resources relative to her expectations and education, excluded from the main networks of privilege and deeply frustrated with the system. An Islamist party would be supported as long as it is a credible vehicle of protest.

The horizontal network supporter profile emerges from recent research that bring insights from social movement theory to bear on the analysis of Islamist movements (see Wiktorowitz (2004) and Baylouny (2004), and particularly Wickham (2002) and Clark (2004)). These studies argue that grievances do not translate automatically into collective action. They conclude that Islamist movements recruit supporters along horizontal, not vertical, lines (as it would be the case in the clientelist profile). In turn, movement organizations should be considered as horizontal networks. As the core of the organizations consists of educated, upwardly mobile, middle class individuals, horizontal recruitment implies that the same type of characteristics would apply to Islamist supporters. These individuals generally stand in the 'middle'. They are neither rich nor poor; struggling, but not for survival (for instance, a doctor moonlighting); not included within a powerful system of privileges, but not abjectly excluded either (for instance, they may have a contact or two in the administration). Islamist movements, and, by extension, Islamist parties are appealing as horizontal networks that connect these individuals. An Islamist voter would thus be an individual who supports what he sees as a party of like-minded individuals. It would be someone who would benefit from increased transparency and better public services promised by many Islamist parties. This individual would vote along programmatic lines. However, rather than asking for radical and/or substantial change (as in the grievance profile), the horizontal network supporter would ask for a change of policies rather than of politics.

We operationalize these profiles for the empirical analysis, making use of three variables (see 4th column in Table 1): education, wealth and exclusion from state networks. Different combinations of these variables capture the essence of each of the profiles. In the clientelistic-type of explanation, the supporter would be poor, excluded and uneducated. A grievance explanation would imply that Islamist voters generally have little wealth/inclusion relative to their aspirations, especially when they have a higher level of education. In the horizontal network explanation, Islamist supporters would be highly educated, but not poor or excluded.

As our data are not at the individual but at the district level (see section 4), we make inferences by comparing districts. If party-voter linkages were of a clientelistic type, the PJD should do better in districts (see column 5 in Table 1) with low education levels. If the grievance explanation held in Morocco, the electoral results should be better in districts with a high level of education and, conditional on education, better in poorer and excluded districts. Finally, horizontal network voters should be prominent if the PJD did better in districts with a high level of education and, conditional on education, support were unrelated to wealth and exclusion. 


\section{Political parties and Islamist groups in Morocco}

The political system in Morocco is best described as an authoritarian monarchy. Political parties have existed since independence in 1956, but the real power is concentrated in the palace. There are essentially two types of political parties. First, the so-called 'palace parties' created by and/or loyal to the king, including the Mouvement Populaire (MP), the Rassemblement National des Indépendants (RNI) and the Union Constitutionnelle (UC). Second, the socalled 'traditional opposition', including the Istiqlal party, the leftist Union Socialiste des Forces Populaires (USFP) and the once-communist Parti du Progres et du Socialisme (PPS). ${ }^{7}$ Up to the mid-1990s, parliament was only partially directly elected and wielded little power; massive electoral fraud ensured the domination by the palace parties. ${ }^{8}$

In the 1990s, King Hassan II enacted political liberalization measures, including two constitutional reforms that transferred more power to the elected government and parliament, introduced a second chamber and provided for the direct election of parliament. Elections became gradually more transparent. In 1997, in what came to be known as the alternance, the traditional opposition parties were asked by the king to form a government. The emerging government was headed by the USFP, including the Istiqlal and the PPS, and also some palace parties. Much hope was placed in the alternance to change politics - and the configuration of political power - in Morocco (Ferrié, 1999; Tozy, 1999b). The performance of the alternance government, including its record on human rights and social policies was disappointing, however, and popular enthusiasm soon faded. ${ }^{9}$ The same applies to the subsequent government (2002-2007) composed of the same parties.

Despite these reforms, the king did keep a firm grip on power, helped by the dividedness of opposition forces. For instance, the king controls key ministries (such as the Ministry of the Interior and Defence), appoints the secretaries of state of all ministries, all the governors, judges and magistrates and controls the military (Maghraoui, 2002). This configuration of power remained unchanged under King Hassan II's successor Mohammed VI, but could potentially be challenged by a united government that asserts the constitutional right of representative political institutions vis-à-vis the monarchy. Recent Moroccan elections are considered much less fraudulent than most elections in other MENA countries: benefiting from a fragmented opposition, regime intervention into elections mainly consists of very active gerrymandering and of tolerating vote buying (Storm, 2008).

The Islamist movement in Morocco can be divided into two main strands. Justice and Charity is considered the most popular (Cavatorta, 2007). It refuses to participate in elections under the current conditions ${ }^{10}$ and instructs its members to boycott elections. ${ }^{11}$ The second strand is the
Movement of Unity and Reform (MUR). This group had wanted to participate in the political process since the late 1980 s, and is the one behind the creation of the Party of Justice and Development (PJD). The two strands of the Islamist movement are believed to be mainly urban in their outreach (Munson, 1986). ${ }^{12}$

The PJD first participated in elections in $1997 .{ }^{13}$ Since then, it has gradually grown stronger, increasing its (official) votes from around 250,000 (nine seats out of 325) in 1997 to around half a million votes (42 seats out of 325 ) in 2002. In the legislative elections of 2007 , the party was expected to win by a landslide. ${ }^{14}$ However, it only increased its seats by two and lost close to 100,000 votes. That the PJD tripled its seats while doubling its votes only from 1997 to 2002 is mainly the result of a change of electoral law between these elections. Up to the 2000s, elections in Morocco were held under a simple first-past-the-post system. A new law before the 2002 elections changed this into a closed list proportional system, a reform promoted by opposition parties, including the PJD. A 3 percent threshold was introduced. The district magnitude of the new districts remained small, with a minimum of two and a maximum of five seats per district. The average district magnitude being 3.25 in 2002 and 3.1 in 2007, the new electoral system looks rather like a disguised majority system (Santucci, 2005).

The PJD's original platform and parliamentary interventions focused on typical Islamist items, such as authenticity, morality, the promotion of Morocco's Islamic identity, arabization, the evils of alcohol, the liberation of Palestine and the like (see Willis (1999) and Wegner (2007)). Importantly, the party added the demand for constitutional reforms - aimed to strengthen the rule of law and the prerogatives of representative institutions - to its platform after the death of King Hassan II in 1999 (Wegner, 2011). Given the low levels of trust Moroccans have in political parties, the party's focus on hard work and the integrity of its MPs as well as the grassroots campaigns run by party members and Islamist activists were at least equally relevant for establishing its profile as a party that would make a difference (ibid.). Over the years, the PJD's platform became more elaborate and the party's campaigns more professional. In 2007 - for reasons that will be discussed below - the party's platform changed to address more seriously economic and social policies and grassroots campaigning decreased considerably.

\section{Data}

The study is based on an original dataset consisting of merged data on electoral results and the 2004 census. Election data cover the elections of 2002 and 2007. In both years the election data include the votes received by all parties, as well as the turnout and the number of null votes at the electoral district level. ${ }^{15}$ The census data are aggregated 
at the municipal level, with 1692 municipalities. ${ }^{16}$ The data include socio-economic variables, such as population, age, gender, education and certain occupation categories, as well as housing variables, such as the type and age of houses, access to electricity and water, and household items such as satellite dishes, telephones and WCs. ${ }^{17}$

The merging of census and electoral data was based on the administrative units published in the Bulletin Officiel of 15 August 2002 for 2002, and the Bulletin Officiel of 5 April 2007 for 2007. Notice that the same census data are used for the two elections. The merging was somewhat more problematic for 2002 , because some administrative units changed between 2002 and 2004, the year of the census. For robustness checks, we rely on an alternative source of data that includes some of the relevant census variables. These data come from the National Documentation Center also belonging to the Haut Commissariat du Plan. The data are already aggregated at the electoral district level so that there are no merging problems. However, since the merging process of these data is not transparent, we use the original census data for the main analysis.

Electoral and census data appear to be relatively reliable. As mentioned, official electoral results in 2002 and 2007 can be considered as reasonably accurate; in 2007, international observers who had been allowed to monitor the elections concluded that they had been transparent (NDI, 2007). The major complaints were about vote buying and were voiced loudly by the PJD itself. For our purposes, this is unproblematic: an individual who sells her vote to another party is rightly considered as not supporting the Islamist party. Regarding the census data, some basic patterns appear as expected. For instance, the degree of urbanization correlates strongly with illiteracy; most college graduates and satellite dishes are found in Rabat Ocean and in Casablanca Anfa, which are upmarket neighbourhoods of political and economic capital, respectively; most slums are found around Casablanca and these display low education, low level occupations and few household comfort items.

The main dependent variable used is PJD votes as a percent of registered voters. This is the closest indicator for PJD support in the population. It differs substantially from the percent of cast votes received by the PJD because turnout varies systematically with PJD success. For example, in 2007, in certain districts of Casablanca, among those that voted a large proportion voted for the PJD (around 30 percent), but turnout was unusually low there, around 25 percent, so that only around 7 percent of registered voters actually supported the PJD. Abstentionists should be considered to have made a choice not to support any party; the figure of 7 percent therefore reflects better PJD support in these districts of Casablanca than that of 30 percent.

The explanatory variables to be used are proxies for the variables arising in the profiles of Islamist supporters discussed above: education, wealth and exclusion from state networks. For education, we use mainly literacy, although we also use university education for robustness checks. For wealth, we use the percent of satellite dishes and the percent of mobile phones for robustness checks. Although satellite dishes and mobile phones can be seen often in poor areas, even in slums, they do appear to be a good proxy for wealth. According to our data there is a large variation in these variables across circumscriptions. The percent of satellite dishes ranges from 7 to 62 , while the figures for mobile phones are 26 percent and 81 percent. Moreover, the circumscriptions with the lowest percentages have characteristics that make them indeed appear as poor, such as very low literacy rates, very low percent of employers, of villas, etc., while the reverse applies to the circumscriptions with high percent of mobile phones and satellite dishes. ${ }^{18}$ Exclusion from state networks is proxied by the percent of public employees. Providing public employment is generally considered a deliberate cooptation strategy of authoritarian regimes (see, for instance, Levitsky and Way (2010) and Yom (2009)). By extension, areas where regimes provide more public employment than in other, similar, areas can be seen as particular targets of inclusion into state networks. Besides these variables, as a complement, we use the degree of urbanization, some occupational categories and housing types. Table 2 shows the mean, minimum, maximum values and intermediate quartiles of these variables in the dataset. ${ }^{19}$

An important concern regarding the data is the degree of aggregation and, in particular, the potential for incurring ecological fallacy. Essentially, the use of district level data means that inferences, say, on education, are drawn by comparing voting results of districts with many educated individuals to those with few educated individuals. The ecological fallacy would imply that even if the PJD obtains more votes in districts with more educated individuals, it does not follow that it is the educated themselves that have more propensity to vote for the PJD. The risk of ecological fallacy decreases the more homogenous districts are internally and the more heterogeneity there is across districts. This is a potentially important concern for our analysis, since the districts in our data are relatively large: the number of districts in the analysis is only 95 (91 for 2002), with an average population of around 300,000 . We believe, however, that there is sufficient heterogeneity across districts in the variables of interest to perform a meaningful analysis. Our key explanatory variables are literacy and satellite dishes. As can be seen from Table 2 , literacy levels cover a wide range, from 30 to 80 percent, with a quarter of the observations below 45 percent and another quarter above 65 percent. For satellite dishes, districts range from 7 percent to 61 percent, with a quarter of the observations below 20 percent and another quarter above 41 percent. 
Table 2. Summary of variables.

\begin{tabular}{|c|c|c|c|c|c|c|c|}
\hline & PJD votes & Mean & Min & Ist quarter & Median & $\begin{array}{c}3 r d \\
\text { quarter }\end{array}$ & Max. \\
\hline & Urban & 55 & 7 & 29 & 51 & 79 & 100 \\
\hline \multirow[t]{2}{*}{ Education } & Literacy & 56 & 31 & 48 & 54 & 65 & 81 \\
\hline & College & 5 & 1 & 3 & 4 & 5 & 20 \\
\hline \multirow[t]{2}{*}{ Resources } & Satellite & 32 & 9 & 21 & 31 & 41 & 63 \\
\hline & Mobile phone & 58 & 27 & 49 & 57 & 68 & 82 \\
\hline \multirow[t]{7}{*}{ Occupation } & Employer & 2 & 0 & I & 2 & 2 & 6 \\
\hline & Self-employed with shop & 21 & 7 & 14 & 22 & 27 & 35 \\
\hline & Self-employed at home & 2 & 0 & I & 2 & 3 & II \\
\hline & Self-employed street vendor & 7 & 2 & 5 & 7 & 9 & 14 \\
\hline & Public employee & 14 & 3 & 8 & 10 & 16 & 53 \\
\hline & Private employee & 39 & 9 & 29 & 37 & 48 & 68 \\
\hline & Helping the family & 14 & 1 & 4 & 13 & 22 & 49 \\
\hline \multirow[t]{3}{*}{ Housing type } & Villa & 2 & 0 & 0 & I & 2 & 10 \\
\hline & Apartment & 5 & 0 & I & I & 6 & 46 \\
\hline & Moroccan house & 48 & 9 & 35 & 49 & 64 & 89 \\
\hline
\end{tabular}

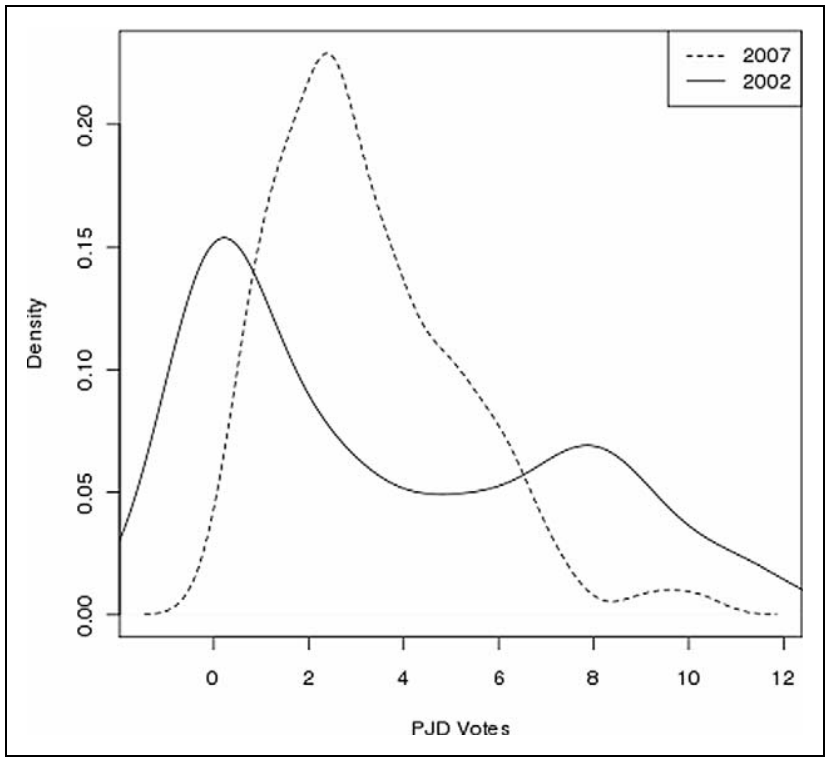

Figure I. Density of PJD votes 2002 and 2007.

\section{Commonalities between 2002 and 2007: No clientelist support profile}

\section{Profile of PJD strongholds}

Figure 1 shows the distribution of PJD support across districts for 2002 and 2007. The figure displays the kernel density of districts in which the PJD obtained different levels of support. The first feature to notice is how small the numbers on the horizontal axis are. In most districts, only a small minority of registered voters cast their ballot for the PJD. In the few districts where the PJD did extraordinarily well, only around 10 percent of these voted for them in any given year. That one of the strongest parties in Morocco appeals to such a small fraction of the electorate highlights, on the one hand, the degree of disaffection of the Moroccan population with the type of elections offered by the palace and the fragmentation of the Moroccan party system, on the other.

The second observation is that one can distinguish several groups of districts on the basis of PJD support. This is most clear in 2002, with two pronounced humps with modes at 8 percent and at 0 percent, reflecting the PJD strongholds and the districts where the PJD did poorly or chose not to run. ${ }^{20}$ In 2007, there are also two main groups (with humps at 3 percent and 6 percent), plus two outliers where the PJD had exceptionally high support. ${ }^{21}$

In which way do PJD strongholds differ from districts where the PJD enjoys little support? Table 3 shows the profiles of districts with different levels of PJD support in both elections. PJD strongholds have a characteristic profile. They are more urban, wealthier and more educated than average. They also display more public and private employees but less self-employed, and more apartments and villas but less rural houses. ${ }^{22}$

\section{Clientelism? Education and PJD support}

The urban character and above average education found in PJD strongholds provides some first evidence against the Clientelist-type of profile. In this section, we evaluate these commonalities of the PJD voter profile in more detail. First, we study more closely the relationship between PJD votes and education and consider whether the educated profile of PJD voters might be the outcome of other factors, such as the degree of urbanization. Second, we study how turnout is related to PJD votes. Third, we compare the PJD to other Moroccan parties, demonstrating that the PJD stands out as the only Moroccan party whose electorate appears to be voting on a programmatic basis rather than having clientelistic motivations for its support. 
Table 3. Profile of districts with different levels of PJD support.

\begin{tabular}{|c|c|c|c|c|c|c|c|}
\hline & \multirow[b]{2}{*}{ PJD votes } & \multicolumn{3}{|c|}{2002} & \multicolumn{3}{|c|}{2007} \\
\hline & & $\begin{array}{c}\text { Not } \\
\text { covered }\end{array}$ & $<6 \%$ & $>6 \%$ & $(0.4)$ & $(4.8)$ & $(8.12)$ \\
\hline & Freq & 35 & 27 & 29 & 68 & 24 & 2 \\
\hline & Urban & 40 & 47 & 80 & 45 & 79 & 50 \\
\hline Education & Literacy & 49 & 52 & 67 & 52 & 67 & 50 \\
\hline & College & 3 & 4 & 7 & 4 & 7 & 3 \\
\hline Resources & Satellite dish & 26 & 29 & 42 & 28 & 42 & 26 \\
\hline & Mobile phone & 51 & 56 & 68 & 54 & 69 & 51 \\
\hline Occupation & Employer & 2 & 2 & 2 & 2 & 2 & 2 \\
\hline & Self-empl with shop & 25 & 22 & 15 & 23 & 15 & 26 \\
\hline & Self-empl at home & 2 & 0 & 2 & 2 & 2 & 5 \\
\hline & Self-empl/street vendor & 7 & 7 & 9 & 7 & 9 & 9 \\
\hline & Public employee & 13 & 12 & 15 & 12 & 16 & 10 \\
\hline & Private employee & 31 & 37 & 50 & 36 & 49 & 27 \\
\hline & Helping the family & 19 & 16 & 6 & 17 & 7 & 21 \\
\hline Housing type & Villa & 1 & I & 3 & 1 & 3 & I \\
\hline & Apartment & I & 4 & 12 & 2 & 14 & I \\
\hline & Moroccan house & 41 & 46 & 59 & 44 & 57 & 48 \\
\hline & Slum & 8 & 7 & 9 & 8 & 10 & 7 \\
\hline & Rural house & 45 & 39 & 13 & 40 & 13 & 41 \\
\hline
\end{tabular}
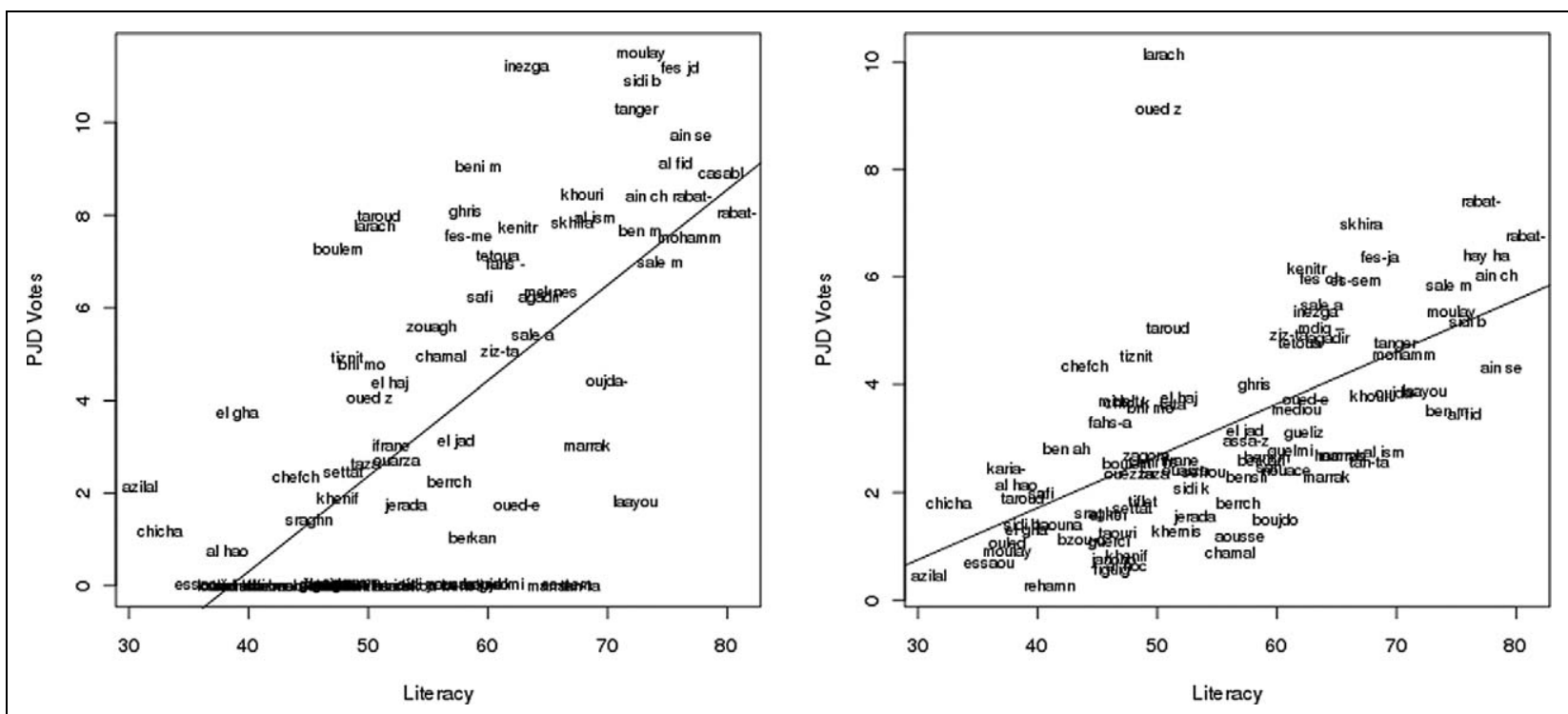

Figure 2. Relation between literacy and PJD votes 2002 (left panel) and 2007 (right panel).

Figure 2 shows that there is a linear and relatively tight positive relation between literacy and PJD support both in 2002 and in 2007. The relation is tighter in 2007, so that the two outliers mentioned above are clearly visible. For 2002 , part of the extra-residual variability comes from the large amount of districts that the PJD did not cover.

The risk of ecological fallacy is always present in analyses of aggregate data like these. We believe, however, that 
Table 4. Regression PJD vote-share on urbanization and literacy.

\begin{tabular}{|c|c|c|c|c|}
\hline \multirow[b]{2}{*}{ (Intercept) } & \multicolumn{2}{|c|}{2002} & \multicolumn{2}{|c|}{2007} \\
\hline & $-0.59(0.66)$ & $-8.27(2.16)^{* *}$ & $\mathrm{I} .24(0.29)^{* *}$ & $-3.57(0.96)^{* *}$ \\
\hline lozTRUE & & & $6.68(0.98) * *$ & $7.21(0.87)^{* *}$ \\
\hline Urban & $0.08(0.01)^{* *}$ & $0.00(0.02)$ & $3.45(0.47) * *$ & $-1.25(0.99)$ \\
\hline Literacy & & $0.22(0.06)^{* *}$ & & $0.13(0.03)^{* *}$ \\
\hline
\end{tabular}

Dependent variable: PJD votes as percent of registered voters.

lozTRUE is a dummy for the districts Larache and Oed Zem Bejaad shown above to be outliers in 2007.

**Significance at the $1 \%$ level; *significance at the $10 \%$ level.

Table 5. Bivariate correlations between literacy, turnout, null votes and party votes.

\begin{tabular}{|c|c|c|c|c|c|c|}
\hline & \multicolumn{3}{|c|}{2002} & \multicolumn{3}{|c|}{2007} \\
\hline & Literacy & Turnout & Nulls/Turnout & Literacy & Turnout & Nulls/Turnout \\
\hline Literacy & I & -0.154 & 0.424 & I & -0.5502 & 0.653 \\
\hline Turnout & -0.154 & I & -0.298 & -0.5502 & I & -0.6464 \\
\hline Nulls/Turnout & 0.424 & -0.298 & I & 0.653 & -0.6464 & I \\
\hline Votes.PJD & 0.688 & -0.283 & 0.447 & 0.6268 & -0.2806 & 0.5426 \\
\hline Votes USFP & 0.214 & -0.029 & 0.219 & -0.2949 & 0.5259 & -0.306 \\
\hline Votes.PI & -0.083 & 0.189 & -0.198 & -0.1366 & 0.5078 & -0.2909 \\
\hline Votes RNI & -0.292 & 0.165 & $-0.34 I$ & -0.1997 & 0.3259 & -0.2638 \\
\hline Votes MP & -0.244 & 0.202 & -0.174 & -0.1205 & 0.3619 & $-0.084 I$ \\
\hline Votes UC & -0.054 & 0.21 & -0.139 & -0.2482 & 0.3357 & -0.2427 \\
\hline
\end{tabular}

the particular pattern shown in the data reduces the concerns about the importance of this fallacy in our analysis. Particularly for 2007, the whole conditional distribution of PJD votes appears to increase in a remarkably constant and uniform way with education. We believe it unlikely that it is precisely the uneducated that are voting for the PJD uniformly more as the percent of educated in the respective district increases, as the ecological fallacy, if correct, would imply. ${ }^{23}$

Nevertheless, biases in our result may still come from variables that are strongly related to education, so that their variation might generate a relation such as the one in Figure 2. We consider potential key sources of bias, starting with factors related to the rural/urban divide. Education is strongly related to urbanization in Morocco and it could be the latter that drives support in reality. In this case, the pattern in the figure would give a biased interference of the role of education - and hence, clientelism - for PJD support. $^{24}$ To explore the possibility of this type of bias, we regress PJD support on urbanization, together with literacy. As Table 4 shows, education appears as strongly related to PJD support in both years, even when accounting for urbanization levels. In fact, it is interesting to note that the effect of urbanization disappears once education is introduced into the regression. This suggests that education is one of the main drivers of the urban/rural divide in PJD support.

Another possible source of bias relevant to our discussion is related to turnout. In many countries, educated individuals tend to be more politicized and vote more (Jackson,
1995; Sondheimer and Green, 2010). Our results could thus simply be driven by higher turnout in more educated districts. However, in authoritarian elections abstention is often a signal of protest and it is generally found to be higher among middle class voters (i.e. the more educated) (Ghandi and Lust-Okar, 2009; Karklins, 1986). The poor and voters in rural areas - usually the less educated - turn out in larger numbers, precisely because they are more vulnerable to clientelistic mobilization strategies (Blaydes, 2006). Indeed, in Morocco, more educated individuals voted less, rather than more in 2002 and 2007; they also cast more null votes (see Table 5). ${ }^{25}$ The result regarding education and PJD support is thus remarkably strong: even if districts with higher education levels tend have lower turnout, the PJD obtained most support in these. Indeed, as the table shows, there is a negative correlation between turnout and PJD votes.

It is noteworthy that the PJD appears to be an exception rather than the norm not only regarding the education pattern of its electorate but also regarding the correlation between support and turnout. As Table 5 shows, the PJD is almost the only party where support is positively related to literacy, abstention and null votes. The opposite is true for most of the other relevant parties in Morocco. ${ }^{26}$ To the extent that illiteracy and high turnout are indicators of clientelistic voting it appears that all other major parties in Morocco rely to some extent on clientelistic linkages. To the extent that abstention and null votes are indicators of protest, the PJD is the only major party successful in 
districts with a protest environment. Compared to other major Moroccan parties, both the former opposition and parties associated closely with the regime, the PJD is thus the only party with a clear non-clientelistic voter profile in 2002 and 2007.

This evidence is reinforced by qualitative evidence on the PJD's party organization. In general, programmatic parties are thought to have a stronger party organization and to exert more control over candidates and elected representatives than clientelistic ones (Desposato, 2006; TaylorRobinson, 2006). Along a similar line, procedures for the selection of candidates and party leaders are likely to be more transparent and institutionalized than in clientelistic parties. ${ }^{27}$ Measured by these criteria, the PJD again stands out among Moroccan parties, where floor crossing is ubiquitous, internal elections are rare and opaque, and secure list positions are often sold in national elections (Santucci, 2001; Willis, 2002b). As Wegner (2011) shows, the PJD has strong voting discipline at both the local and the national level, sanctions floor crossing, has a strong preference for party candidates and has made internal democracy an important part of its identity. ${ }^{28}$

In sum, a clientelistic supporter profile of PJD voters is not supported for the PJD in any election so far. In both 2002 and 2007, the PJD did substantially worse in less educated places, where clientelism ought to be more prevalent. Indeed, consistently with a clientelistic logic, less educated districts did vote more, but these votes went to parties other than the PJD. Moreover, the PJD appears to aim at programmatic rather than clientelistic linkages with the voters.

\section{Differences between 2002 and 2007: From grievances to educated network}

\section{Changes from 2002 to 2007}

Beyond this important commonality, the data reveal differences in the pattern of Islamist support between 2002 and 2007. That changes occurred between the two elections can already be appreciated in the particular distribution of votes across districts, shown in Figure 1. The distribution for 2002 is clearly more dispersed, with more density (districts) at the two extremes. The left side of the graph is partly explained by the fact that in 2002 the PJD did not cover all districts (only 61 percent). The other side is more meaningful from a support perspective: the right hump of 2002 with support around 8 percent moves leftwards in 2007. This suggests that, in 2007, the PJD systematically lost support in its traditional strongholds.

This idea is further evidenced by comparing the districts where the PJD did best. Wegner and Pellicer (2010) compare the top PJD districts in 1997, 2002 and 2007. The data show that the areas where the PJD did best in 1997 and in 2002 essentially coincide. For example, both in 1997 and in 2002 five out of the top ten districts are in Casablanca.

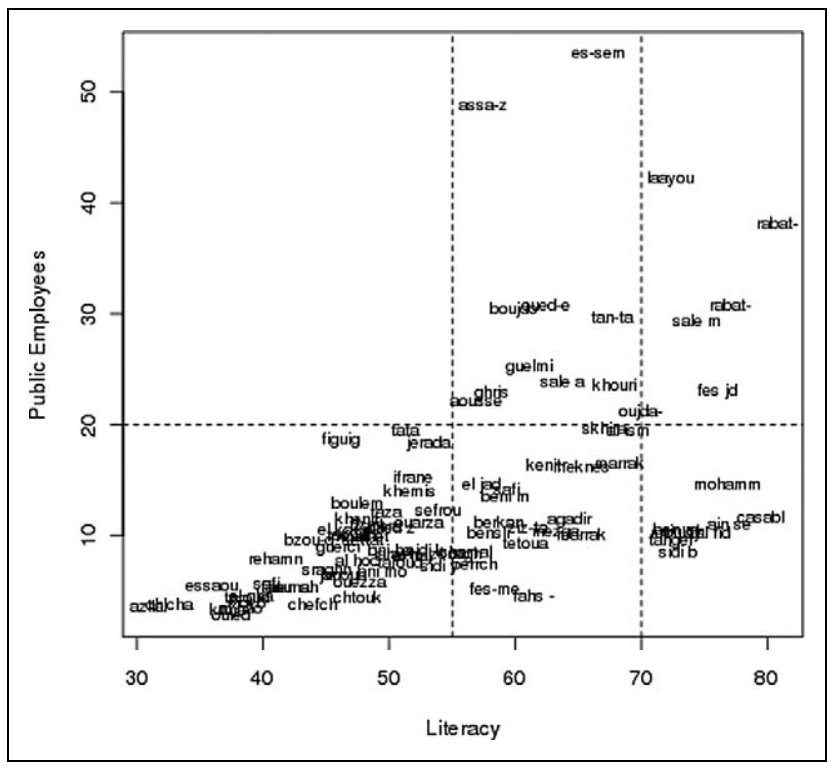

Figure 3. Percent of literacy and public employees (2007).

Other areas that figure prominently in both years are Agadir and Tangier. In 2007, however, the locations differ significantly. Casablanca becomes much less prominent (only two districts among the top ten); Agadir and Tangier disappear, while Rabat rises to prominence and Kenitra appears. In general, there seems to be gravitation away from former strongholds toward the political centre.

\section{From grievance to educated network}

In which way did the pattern of PJD support change? We argue that the change entailed a move from an electorate characterized by a predominantly grievance-type of profile to a predominantly horizontal network type. As discussed above, the PJD was successful particularly in more educated districts, in districts with high aspirations in both elections. The question we now consider is whether, within those districts, the PJD's appeal was larger in more excluded/poorer places, consistent with a grievance type of profile or vice versa, reflecting the educated network profile. In order to answer this question, we divide the districts on the basis of literacy levels and, within each level, we compare PJD results, first, for different values of exclusion, and, second, for different levels of resources. Finally, as robustness checks, we perform regression analyses under different specifications.

Consider first exclusion - proxied by the percent of public employees. Figure 3 shows the percent of literacy and public employees in each 2007 district. $^{29}$ The dotted lines break the districts according to exclusion and education; three education groups, each subdivided in two exclusion groups. At the bottom left of the graph are districts with few literates and few public employees. These are essentially 
Table 6. PJD results by education and inclusion.

\begin{tabular}{|c|c|c|c|c|c|c|c|}
\hline \multirow[b]{2}{*}{2002} & & \multicolumn{6}{|c|}{ Literacy } \\
\hline & & $(0.55)$ & & $(55.70)$ & & $(70.100)$ & \\
\hline \multirow[t]{2}{*}{ Public employees } & $(20.100)$ & & & South & 2.6 & Rabat & 7.3 \\
\hline & $(0.20)$ & Rural & 1.5 & Towns & 5.5 & Csb & 9.3 \\
\hline \multirow[t]{2}{*}{2007} & & \multicolumn{6}{|c|}{ Literacy } \\
\hline & & $(0.55)$ & & $(55,70)$ & & $(70,100)$ & \\
\hline \multirow[t]{2}{*}{ Public employees } & $(20.100)$ & & & South & 3.4 & Rabat & 6 \\
\hline & $(0.20)$ & Rural & 2.4 & Towns & 3.8 & Csb & 4.8 \\
\hline
\end{tabular}

rural districts. The relation between literacy and public employees is relatively tight among them. In this group, there is little variation in exclusion conditional on education - more education is associated with more inclusion. This implies that in this group the identification of grievances vs. horizontal network profiles will be difficult. Beyond this rural group, the variation in public employees for given literacy rates increases substantially, giving rise to identifiable groups. In the middle of the graph are districts with intermediate education levels. Among these, the bottom shows districts with few public employees - essentially the middle sized towns, such as Meknes, Marrakesh, Al Jadida, Agadir, etc. The top displays districts with similar education levels but large amounts of public employees. These are mainly districts in the South, including the annexed Western Sahara. Finally, on the right side of the graph are districts with high education levels. Here, the groups given by exclusion are the starkest. On the bottom right are districts with high literacy but few public employees. These correspond mainly to the Casablanca area. On the top right are districts with abundance of both - essentially Rabat and its periphery.

To disentangle between grievance and education network profiles we need to compare PJD results for given education groups across different degrees of exclusion. We focus particularly on places with intermediate and high levels of education. This is primarily because both the education network and the grievance profiles presuppose a certain degree of aspiration given by education. A second reason is that, as we just saw, in the low education (rural) districts there is little variation of public employees conditional on education. Therefore, the key question to ask is whether the PJD does better in Casablanca as opposed to Rabat, and in middle sized towns as opposed to the South. ${ }^{30}$

Table 6 shows the results, displaying PJD support in different inclusion/education cells, for 2002 and 2007. Consider first the difference in PJD support across education groups (i.e. across columns). For both years, regardless of exclusion, PJD support rises as we move to the right in the table, showing an increase in support in more educated districts. This is the result discussed in section 5 above.
The comparison across rows, for given columns, however, differs across years. In 2002, conditional on education, the PJD did better in more excluded districts (in districts with fewer public employees). In 2007, this effect disappears and PJD support moves away from the grievance profile: The pattern is reversed for the top group of literacy $(70,100)$. In this group, the PJD now won more support in more included districts. In the middle group of literacy $(55,70)$, support in the included and excluded groups almost converges. In fact, the change in the pattern of support is due to the disproportionate losses the PJD suffered in the more excluded areas (Casablanca and Towns). Although the PJD lost support in most districts with the exception of the South and the rural areas, it lost most support in the areas prone to grievance supporters. ${ }^{31}$

We now consider the results using resources. We follow the same procedure as with exclusion. Figure 4 breaks the districts according to literacy and satellite dishes (as Figure 3 did for public employees).

The relation of literacy and satellite dishes is much tighter than with public employees, in this case particularly in high education districts. This implies that attempts at uncovering the effect of resources for given degree of literacy are more difficult than was the case with exclusion. The patterns nevertheless are similar, as shown in Table 7. The pattern of support across wealth groups for given education changes from 2002 to 2007. In 2002, for all education groups, the PJD did better in poorer places relative to richer ones, reflecting a grievance driven supporter profile. In 2007, the results reverse, reflecting a horizontal network profile. As in the case of exclusion, the PJD loses support in all former strongholds, but particularly in those with fewer resources. ${ }^{32}$

In order to verify whether the results in the previous tables were induced by the particular threshold chosen for the groups we perform OLS regressions of PJD votes on literacy and public employees, on the one hand, and on literacy and resources, on the other. The results are given in Table 8 . The first columns show the results of the regressions for 2007 and 2002, using the full sample. The first column considers exclusion and the second column considers resources. 


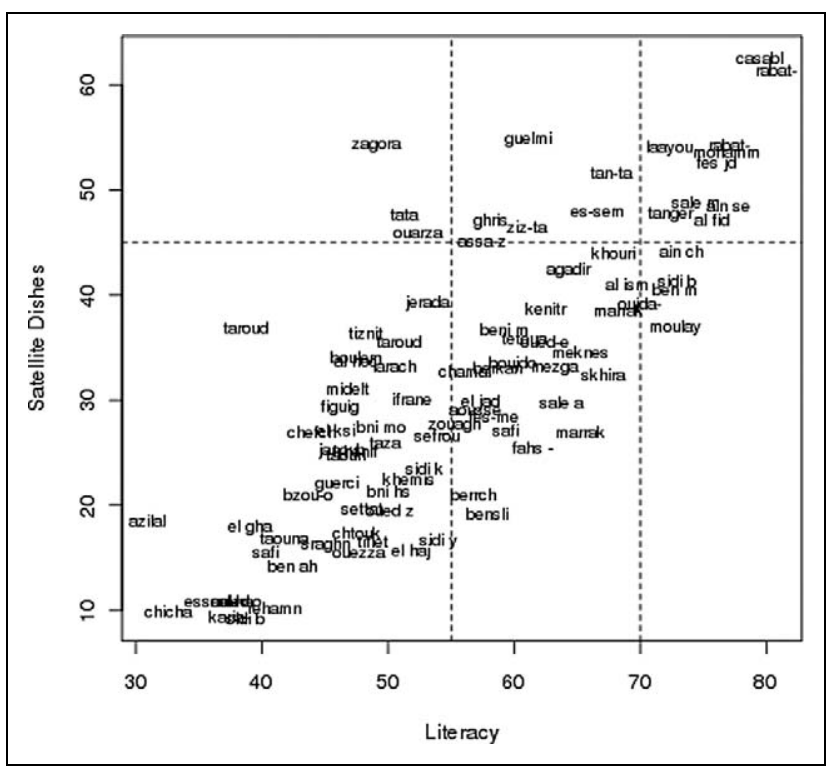

Figure 4. Percent of literacy and satellite dishes (2007).

Table 7. PJD results by education and resources.

\begin{tabular}{llccc}
\hline \multirow{2}{*}{2002} & & \multicolumn{3}{c}{ Literacy } \\
\cline { 3 - 5 } & & $(0.55)$ & $(55,70)$ & $(70,100)$ \\
\hline Satellite dishes & $(45,100)$ & 0.9 & 2.2 & 8.2 \\
& $(0.45)$ & 1.5 & 5 & 9.6 \\
2007 & & & & \\
\multirow{2}{*}{ Satellite dishes } & $(45,100)$ & 2.9 & 3.8 & 5.5 \\
& $(0.45)$ & 2.4 & 3.6 & 4.5 \\
\hline
\end{tabular}

In both cases we control for literacy (and degree of urbanization, in order to make it comparable the regression shown in Table 4). Thus, we obtain the effect of inclusion and resources on PJD votes conditional on education. The results are in line with the evidence shown before: for 2007, the coefficients for public employees and resources are positive and insignificant; for 2002, the signs are reversed: both are negative, and the coefficient for public employees is strongly significant. Therefore, the table shows some evidence that, conditional on education, the PJD had more support in poorer or more excluded places in 2002, but that the pattern broke in 2007. In addition, it is worth noting that, for the two years, the results for urbanization and literacy are the same as in table 4: literacy has a positive and strongly significant coefficient, and urbanization is insignificant throughout. The last columns of the table display the results of the same regression considering only districts with high education (more literacy than the median). In this way we incorporate the fact that grievances require a certain degree of aspirations, proxied by a certain degree of education. The results are essentially the same as before. Inclusion and wealth are positive and insignificant in 2007, and turn negative in 2002. Actually, the results are stronger in this case, since satellite dishes become almost significant at the 90 percent level despite using fewer observations. ${ }^{33}$

Overall, bearing in mind the limitations of the data, we are confident about the message of the data regarding clientelism: the PJD seems consistently to obtain significantly better results in more educated districts. As to the changes from 2002 to 2007 , we find evidence that there has been indeed a change in the pattern of support: the PJD has lost ground in its past strongholds. There is some uncertainty regarding the starting point of the process: For 2002 there is some evidence of a grievance profile, but the evidence is not that strong. The evidence for the end point is stronger: the data suggest quite strongly that the pattern of support in 2007 was that of horizontal network and definitely not of the grievance type.

This last statement is reinforced in an additional interesting manner. Table 9 provides evidence that the party that corresponds to the grievance profile in 2007 is the 'party of abstention'. The pattern is clear: Abstention occurred in places with more education, but with fewer public employees and satellite dishes conditional on education. Interestingly, the pattern is stronger for 2007 than for 2002, suggesting that protest voters had largely abandoned official politics by 2007 .

\section{Evidence from the World Values Survey}

In the following, we discuss data from the World Values Survey (WVS) as a robustness check of our results. The picture that emerges from these data confirms the importance of education for PJD support in 2002 and 2007. It also suggests that PJD support in 2007 resembled a horizontal network type of support, coming from a grievance profile.

The WVS is a widely used survey that has been investigating political, social and cultural attitudes and value change around the world since the 1980s. Morocco was included in the 1999-2004 and the 2005-2008 waves of the WVS. The survey was carried out in Morocco in 20012002 and 2007, respectively. In 2001/2002 before the elections, in 2007 right after the elections (the elections were on the 7 th of September and the survey was carried out from the 15 th to the 7 th of October). The sample sizes for 2001-2002 and 2007 are 2264 and 1200, respectively, and include individuals over 18 years old. In addition to attitudinal variables, the survey includes questions on party support (which party individuals would vote for if there were elections tomorrow), education levels and self-ranking of social class. In our analysis, we recode the education variable to contain completed levels of education (none, primary, secondary and university) with values 0 to 3 . As a measure of wealth we use the self-ranking in terms of 


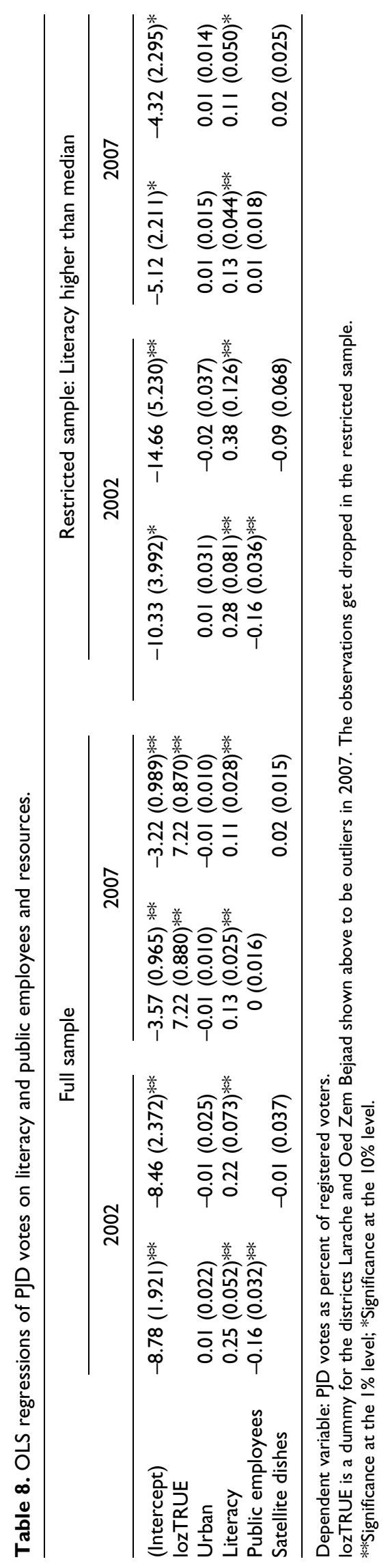


Table 9. The grievance profile of the Party of Abstention.

\begin{tabular}{lcccc}
\hline & \multicolumn{3}{c}{2002} & 2007 \\
\hline Intercept) & $46.33(5.433)^{* *}$ & $42.53(6.610)^{* *}$ & $43.89(6.204)^{* *}$ & $38.31(8.168)^{* * *}$ \\
Urban & $0.16(0.061)^{* *}$ & $0.08(0.068)$ & $0.16(0.066)^{*}$ & $0.04(0.082)$ \\
Literacy & $-0.02(0.148)$ & $0.13(0.203)$ & $0.33(0.164)^{*}$ & $0.52(0.235)^{*}$ \\
Public employees & $-0.46(0.090)^{* *}$ & $-0.83(0.102)^{* *}$ & $-0.31(0.123)^{*}$ \\
Satellite dishes & & $-0.2(0.102)^{*}$ & -0.30 & \\
\hline
\end{tabular}

Dependent variable: Abstentions as percent of registered voters.

**Significance at the I\% level; *Significance at the $10 \%$ level.

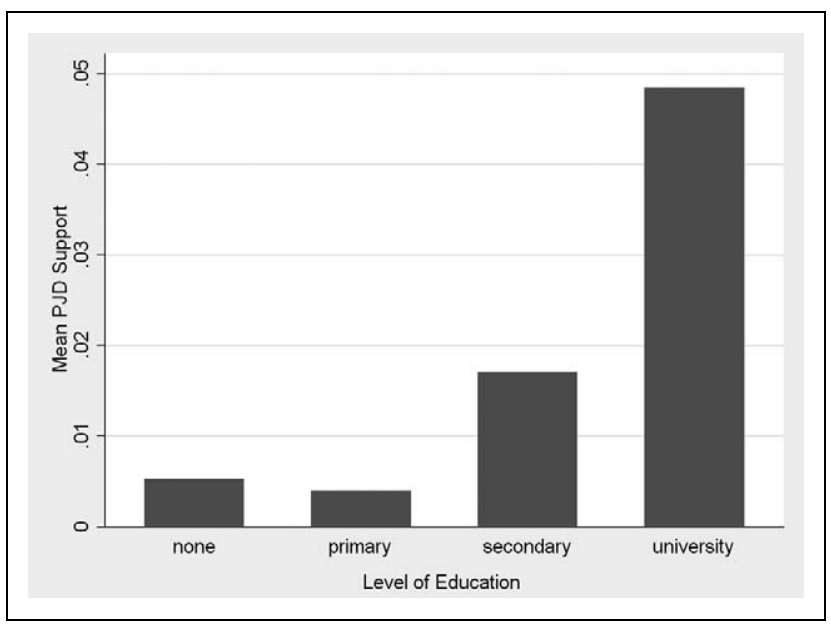

Figure 5. Level of education and PJD support in 2011.

class, which we recode from 'Lower Class', 'Working Class', 'Lower Middle Class', 'Upper Middle Class' and 'Upper Class' to values 0 to 4 , respectively. ${ }^{34}$

While useful to complement our analysis, these data suffer from a number of limitations which prevent us from basing our analysis fully on them. First, in 2001/2002, there are extremely few PJD supporters. Only 19 respondents identified themselves as PJD supporters. This limits severely the ability to draw inferences on the characteristic of these supporters from the sample. In 2007, the number of PJD supporters is substantially higher (243), but the answers on party support are problematic in other respects. There seems to be an over-reporting of PJD support and an under-reporting of abstention compared to the elections held almost contemporaneously. Twenty percent of the respondents identify as PJD supporters compared to the 3.3 percent that actually voted for them. ${ }^{35}$ Even more surprisingly, only 54 percent of the sample said that they would abstain, significantly less than the abstention rate in the 2007 elections (63 percent) and the reported abstention for the latest elections in the same survey ( 62 percent). This suggests that respondents in these surveys feel differently at the moment of the survey than on election day and that their intended support differs significantly from their actual electoral support.

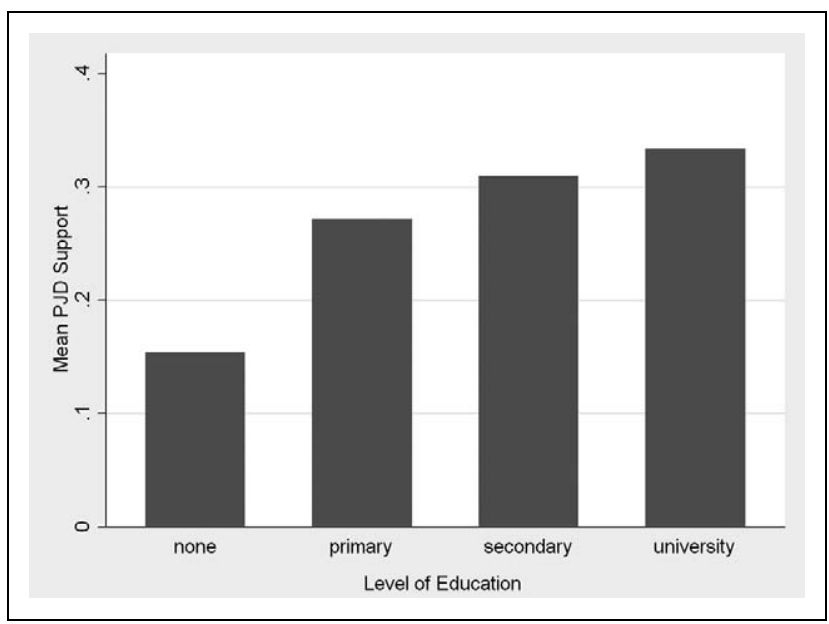

Figure 6. Level of education and PJD support in 2007.

We consider first the link between education and PJD support. Figures 5 and 6 show the percentage of PJD support for different levels of educational attainment in 2001/2002 and 2007, respectively. Unambiguously, PJD support increases with education in both years. The differences are substantial: university graduates are more than twice as likely to vote for the PJD as individuals with no education in both years. For 2007 (where the sample of PJD supporters is higher and therefore point estimates are more trustworthy) the figure increases from 15 percent to more than 30 percent.

To study the role of class conditional on education, we perform a simple regression of PJD support on education and the class variable. The estimates for the two years, using OLS, are presented in Table 10.

The results for both years convey the same message as those we obtained with the district level data. The coefficient for education is positive and strongly significant in both years. It is particularly remarkable that the result for 2002 is significant, given the small number of PJD voters in the sample. The results for class point at an increasing class gradient of PJD support over the time period considered. While for 2002 the class coefficient is essentially zero (actually negative, although highly insignificant), it becomes positive and quite significant for 2007 . 
Table 10. OLS regressions of PJD votes on education and social class in 2002 and 2007.

\begin{tabular}{lcc}
\hline & 2002 & 2007 \\
\hline Intercept & $0.005(0.003)^{* *}$ & $0.12(0.023)^{* *}$ \\
Education & $0.008(0.003)^{* *}$ & $0.06(0.014)^{* *}$ \\
Class & $-0.0001(0.002)$ & $0.03(0.017)^{*}$ \\
\hline
\end{tabular}

Dependent variable: PJD vote intention. Standard errors in parentheses. **Significance at the $1 \%$ level; *Significance at the $10 \%$ level.

In sum, the data from the WVS increase our confidence in our previous findings on PJD support in Morocco. They confirm the importance of education for PJD support and lend further evidence to the hypothesis of a change in the pattern of support towards horizontal network and away from grievance. Interestingly, as was the case with the aggregate data, the evidence for the horizontal network profile in 2007 is stronger than that for the grievance profile in 2002.

\section{The PJD's mobilization pattern: From opposition to technocracy}

Qualitative evidence on the PJD's mobilization pattern since the late 1990s additionally supports our conclusion that the profile of PJD supporters is likely to have evolved from grievance to the horizontal network type of profile. As argued in section 2, the potential appeal of Islamist parties for grievance-driven citizens stems from the oppositional stance many Islamist groups take towards their political regimes and the established elites. Thus, grievance voters would support an Islamist party as long as this party represents a credible opposition and mobilizes energetically. In contrast, horizontal network voters want incremental change only. Being better off than grievance voters, they would support an Islamist party platform focusing on better services, anti-corruption and efficiency.

Analysing the PJD's mobilization pattern we see indeed a change from a more decisive oppositional profile in the late 1990 s and early 2000 s to one that focuses more on concrete socio-economic policies afterwards. The PJD positioned itself as a clear opposition party after the death of King Hassan II in 1999 - two years after the party's first electoral participation. Although it never confronted the regime directly or advocated radical change and policies, it did mobilize strongly against established political elites and their practices and pushed for constitutional reforms. Its key message was its difference to other political parties in Morocco (Wegner, 2007, 2011). In the context of the co-optation of the former opposition into government and their inability to achieve meaningful and visible political change and socio-economic development, the PJD established itself successfully as the only credible alternative to voters. Its electoral platform in 2002 included calls for substantial constitutional changes. The party could count on the full support of the Islamist Movement of Unity and Reform (MUR), who urged its activists to mobilize for the party and ran a full-fledged campaign for it in its newspaper, al-Tajdid (Wegner, 2011). In the 2002 elections, PJD votes more than doubled compared to 1997and the party's share of seats more than tripled. In combination with the analysis of the electoral data above, we suggest that a substantial part of these new voters came from grievance voters who saw the PJD as an outlet for political protest and for signalling their disaffection with the establishment.

The PJD remained in opposition after these elections and first continued along previous lines. This, however, changed dramatically after Islamist terrorist attacks in 2003 allowed political elites to effectively lay the blame on the PJD. Fearing for the legal survival of the party, the leadership adjusted the themes, intensity and locus of its political mobilization. The PJD started to focus on management/administration, development and growth. This was already the case for the municipal elections in the autumn of 2003 and remained so for the 2007 parliamentary elections. The style of its mobilization also changed away from street protest to the political institutions (i.e. proposing amendments, work in the parliamentary committees). Having dropped unconditional support of Islamic identity themes, the party also lost the blessing of the MUR, which ceased to lend a hand in the party's campaign in 2007 (Wegner, 2011; Wegner and Pellicer, 2010). For these elections, the party invested heavily in a new platform that targeted middle class voters, that is, essentially the horizontal network type of voters (ibid.). The party took special care to present itself as a competent respectable party fit for cabinet participation. In these elections, the PJD lost close to 100,000 votes, although by simply maintaining previous support levels these votes should have increased 'mechanically' given that the party had covered the totality of electoral districts for the first time. Combined with the analysis above, we suggest that the voters lost by the PJD consisted chiefly of grievance voters, who, having lost a party via which to articulate their protest, abstained this time (see Table 9). Horizontal network voters, in contrast, became the key electoral basis of the party. Indeed, this corresponds to the PJD's own perceptions about its 2007 electorate: party leaders unanimously believed the middle class to be their key electorate. $^{36}$

In sum, changes in the PJD's mobilization pattern match well the changes in the electorate suggested by our analysis of electoral data. When it mobilized as an opposition party, the PJD attracted grievance voters, once it ceased to do so, it was considered as yet another co-opted party, and grievance voters abandoned it again. Horizontal network voters kept their support and potentially increased it alongside the PJD's heavy targeting of them. 


\section{Conclusion}

This article studied patterns of electoral support for the Moroccan Islamist party in 2002 and 2007. The key commonality found across time was that voters did not support the PJD for clientelistic reasons: PJD voters were too highly educated to vote for such motives. Besides, the profile of PJD voters was changing between 2002 and 2007, in tandem with the party's mobilization decisions. Whereas the party initially attracted grievance voters, interested in voicing their disaffection with the system and the elites sustaining and benefiting from it, it ceased to do so once it adopted a tamer attitude towards the regime. Instead, the party attracted a middle class type of voter interested in incremental change. Grievances were then voiced either by abstaining or by casting null votes.

Our findings thus suggest that voters of Islamist parties are not a stable group of staunch Islamist activists casting a sure vote for ideological reasons. Rather, support for Islamist parties is fluid. On the one hand, it depends on factors relating to the policies offered by a specific party and how credible the party is to the voters. On the other hand, it is influenced by factors that vary across countries, such as, for instance, the size of the welfare organizations of the Islamist organizations associated with the party. Indeed, a possible reason behind the incapacity of the Moroccan Islamists to attract poor and less educated voters might be that, compared to Islamist movements in the Mashrek, such as the Muslim Brotherhoods in Jordan and Egypt or Hizbullah in Lebanon, their welfare efforts are small. In these countries, support for the Islamists might well follow a different logic, possibly resembling more the clientelistic profile.

Finally, our study suggests that the strength displayed by the Moroccan Islamists in 2002 - when it doubled the number of votes received - was largely the result of positioning itself as a credible opposition. This might be true for other Islamist parties as well, given that other opposition groups have largely been co-opted and regimes in power lack legitimacy. Here, however, political parties in semiauthoritarian regimes walk a thin line: while too little protest might alienate voters, too much might prompt re-exclusion from official politics.

\section{Acknowledgements}

We thank Ellen Lust, Francesco Cavatorta and Michael Willis for helpful comments on earlier versions of this article. We acknowledge the comments of participants at the seminar series of the Council on Middle East Studies of the Macmillan Center at Yale University, of the APSA panel on 'Exploiting Elections', of the SOAS seminar series 'Political Economy of Development' and of an anonymous reviewer of this journal. All remaining errors are ours.

\section{Notes}

1. The 2001/2002 World Values Survey data used by Garcia Rivero and Kotze contain only 19 supporters of the Islamist party in Morocco. The Arab Barometer data have 16 observations of Islamist party support for Jordan, 66 in Algeria (much lower than in elections), 106 for Yemen and 121 for Morocco. Only for the West Bank and Gaza does the figure reach 500.

2. The figure that is widely quoted is 13.5 percent of votes; it corresponds to PJD votes as percentage of the votes cast.

3. This could imply that it is rather the actual results that underrepresent Islamist support due to fraud. For this particular Moroccan election, however, there was no indication of fraud of that magnitude (see below).

4. For our purpose of extracting measurable profiles from the literature, we necessarily need to simplify strongly. We are thus unable to incorporate more nuanced accounts, such as those of Kepel (2000) or Roy (1992). Kepel stresses the alliance of the poor Youth that are products of the rural exode, a pious bourgeoisie and university graduates that could be seen in many movements from the 1970s to the 1990s; Roy emphasizes the categories of the 'lumpenintelligentisa' and university graduates in Islamist movements.

5. See also Cammett and Issar (2010), who argue that differences in service delivery strategies of Islamist organizations in Lebanon are due to different electoral concerns of these organizations.

6. Palmer Harik (1996) refers to a similar type of profile as 'political alienation'.

7. For political parties in Morocco, see Santucci (2001) and Willis $(2002 a, b)$.

8. See Storm (2007) for political development in Morocco since independence and political liberalization in the 1990s.

9. For the performance of the alternance government, see Ferrié (2002) and Hidass (2001).

10. Crucially, the group refuses to recognize the King's religious authority - a precondition for political participation in Morocco (Tozy, 1999a).

11. Justice and Charity activists, however, might not always follow these instructions and are thought to be among the PJD voters (Willis, 2004).

12. For the Islamist movement in Morocco, see especially Tozy (1999a), Shahin (1997) and Zeghal (2005).

13. For a detailed analysis tracing the path of the PJD, see Wegner (2011).

14. A much publicized poll by the International Republican Institute attributed 47 percent vote intention to the PJD.

15. In 2002 there were 91 multi-member electoral districts; in 2007 there were 95 . The 2002 election results were published in REMALD 2003. The 2007 election results were published by the Moroccan interior ministry (available at http://www. elections.gov.ma/index.aspx).

16. Out in the countryside, municipalities are collections of villages; in large cities they represent rather the neighbourhood level.

17. The census data used in this study were obtained directly from the department of statistics of the Haut Commissariat $d u$ Plan in Rabat. Most of the data are also available at the website of the Haut Commissariat (http://www.hcp.ma/ 
Profil.aspx). Some of the variables of the online version, however, are defined slightly differently.

18. A good illustration of the variation in satellite dishes following differences in wealth levels comes from comparing the districts in Casablanca. In slum districts (those with more than 50 percent of slums), only 16 percent had satellite dishes. In contrast, in richer districts (with less than 10 percent of slums), 52 percent had satellite dishes.

19. As shown in the table, no district is uniformly wealthy (the district with most villas has only 10 percent). Thus, the upper end of the distribution will not be well captured.

20. In 2002, the PJD covered only around 60 percent of the electoral districts. Limited coverage in these as well as the 1997 elections was imposed by the regime as a condition for electoral participation. The choice of the covered districts was left to the PJD. Assuming that the party chose to cover districts where it knew it had support, the profile of non-covered districts is still meaningful for analysing the PJD's support.

21. These outliers are Larache and Oued Zem-Bejaad, where the PJD has governed an important town since 2003 (Ksar el Kbir and Oued Zem, respectively).

22. This holds with the exception of the last column - representing the outliers Larache and Oued Zem-Bejaad - in 2007. These two are not more urban, more educated, etc. Quite the contrary, they are very similar to those where the PJD did badly and should be considered squarely 'average' places in Morocco: average education, occupational structure, etc. The high levels of support in these two districts are probably the result of PJD government of these towns. Pellicer and Wegner (2009) show how PJD votes in these towns increased in tandem with a skyrocketing of investment expenditures. This might suggest that the PJD is not adverse to a clientelistic linkage strategy per se once it gains access to the necessary resources through governance. It could also imply that citizens simply reward the development efforts of local politicians in towns that have been neglected previously.

23. Indeed, a more erratic conditional distribution would make an ecological fallacy more of a concern. Suppose that the whole positive relation were driven by the few districts with high levels of education displaying high PJD votes. Then it would be possible that it is the uneducated in those districts that, for some reason emerging from the particularities of those districts, vote in larger numbers for the PJD.

24. Some aspects of the rural/urban divide can be meaningful for clientelism; for instance, the type of social structure. But the rural/urban divide of Islamist support in Morocco could also be unrelated to clientelism given that the Moroccan Islamist movement has most activists in towns (Munson, 1986).

25. For similar trends in abstention in other MENA countries, see Tlemcani (2007). Electoral Authoritarianism, Al Ahram Weekly.

26. The only exception is the USFP in 2002, the party less associated with clientelism in the Moroccan system. Until the alternance, this was an urban party with a protest agenda. In the first post-alternance elections, parts of this past USFP identity are still evidenced, however, the pattern disappears for the USFP in 2007, as the party lost credibility by its government participation and tame attitude towards the regime.

27. These indicators are most appropriate for the more traditional clientelistic parties found in Arab countries and sub-Saharan Africa (Van de Walle, 2007). They do not necessarily hold for the machine-type of clientelistic party that will also have a strong and centralized party organization.

28. The party also changed its top leadership in both the 2004 and 2008 party congresses as an outcome of internal elections.

29. The 2002 graph is essentially the same. Recall that demographic characteristics are taken from the 2004 census and so are taken to be the same in the two elections.

30. We are confident that these groups do indeed capture different levels of inclusion into state networks and that the percentage of public employees is thus a good indicator of inclusion in Morocco. This is quite clear when considering the case of the South compared to the middle sized towns. The Southern districts - displaying a high degree of public employees given their literacy - border or belong to the Western Sahara, a disputed area at the core of Moroccan foreign policy and nationalist mobilization. Their cooptation into state networks of privilege is thus crucial and the fact that turnout there is much higher (52 percent) and null votes much lower ( 16 percent) than in the middle sized towns ( 32 and 22 percent, respectively) shows that the strategy is rather successful. A similar picture emerges from the comparison among the highly educated districts, although much less extreme, with the Rabat area displaying 37 percent of turnout and 22 percent of null votes versus the Casablanca area where the figures are 26 and 27 percent, respectively.

31. The increase of support in the south and in the rural areas is mostly due to the fact that these districts had not been covered in 2002 .

32. Notice that the values of PJD support are not the same as in the table using exclusion because the groups formed by using public employees are not the same as those using resources as the grouping variable. Resources are thus to a certain extent independent from the share of public employees. That the conclusions are the same thus means that the analysis using resources provides a useful robustness check of our main results.

33. As a further robustness check, the analysis was repeated using different specifications (available upon request). First, we used different proxies - university education as a proxy for education and mobile phones and percent of people working in the liberal professions as proxy for resources. Second, we repeated the analysis using the alternative dataset for 2002, where we are also able to use primary and secondary school as proxy for education. The results regarding education are very robust. In all specifications, the education proxy appears positive and significant, confirming the results in section 5 . The same applies to exclusion: public employees appear insignificant in 2007 and negative and significant in 2002 even using the alternative dataset. Regarding resources, 
results were robust for 2007 (always insignificant), but less so for 2002 (generally the proxy for resources failed to be significant and in one case was even positive).

34. The self-ranking of respondents in terms of 'class' was the only wealth indicator available in both surveys. In 2001/ 2002, respondents were also asked to position themselves in income brackets. Given that this correlated strongly with the social class indicated by respondents, we consider the latter to be an appropriate indicator of wealth.

35. The discrepancy is even greater than these numbers suggest, because the percent in the sample is of the total population over 18 , while the actual percent is only over registered voters, a smaller denominator.

36. Authors' interviews in November 2007. Some were more precise in terms of income, stating that key supporters were 'people with an income between 7,000 and 10,000-15,000 dirham (DH) per month' (interview, Rabat, 6 November 2007). For comparison, the legal minimum wage is $1900 \mathrm{DH}$; the average private wage in the formal sector is 4,000 and the average public wage $10,000 \mathrm{DH}$. Others defined the boundaries in terms of occupation, with supporters being somewhere between primary school teachers and medical doctors (interview, Rabat, 5 November 2007). Other types of characterizations were: 'Someone who doesn't struggle for basic needs and cares about leisure'; and, perhaps the most illuminating: 'People that have a house with two rooms, but would need 3 or 4 ; that have a small car but would like a bigger one' (authors' interviews, Rabat, 5 and 6 November 2007, respectively).

\section{References}

Baylouny AM (2004) Emotions, poverty, or politics? Misconceptions about Islamist movements. Quarterly Journal 3(1): $41-47$.

Blaydes L (2006) Who votes in authoritarian elections and why? Vote buying, turnout, and spoiled ballots in contemporary Egypt. APSA Annual Meeting, Philadelphia.

Cammett M and Issar S (2010) Bricks and mortar clientelism: Sectarianism and the logics of welfare allocation in Lebanon. World Politics 62(3): 381-421.

Carvalho J (2009) A Theory of the Islamic Revival. University of Oxford.

Cavatorta F (2007) Neither participation nor revolution: The strategy of the Moroccan Jamiat al-Adl wal-Ihsan. Mediterranean Politics 12(3): 381-397.

Clark JA (2004) Social movement theory and patron-clientelism. Islamic social institutions and the middle class in Egypt, Jordan, and Yemen. Comparative Political Studies 37(8): 941-968.

Desposato SW (2006) How informal electoral institutions shape the Brazilian electoral arena. In: Helmke G and Levitsky S (eds) Informal Institutions and Democracy Lessons from Latin America. Baltimore, MD: Johns Hopkins University Press, pp. 56-68.
Ferrié J-N (1999) La mise en place de l'alternance. Annuaire De l'Afrique Du Nord 38: 231-244.

Ferrié J-N (2002) Fin de partie: l'échec politique de l'alternance et la transition prolongée. Annuaire De l'Afrique Du Nord 40: 308-324.

Fuller GE (2003) The Future of Political Islam. New York: Palgrave Macmillan.

Garcia-Rivero C and Kotze H (2007) Electoral support for Islamic parties in the Middle East and North Africa. Party Politics 13(5): 611-636.

Ghandi J and Lust-Okar E (2009) Elections under authoritarianism. Annual Review of Political Science 12: 403-422.

Henry M Jr (1986) The social base of Islamic militancy in Morocco. Middle East Journal 40(2): 267.

Hidass A (2001) La liberté d'opinion et d'expression au Maroc: normes contingentements et transition démocratique. Annuaire De l'Afrique Du Nord 39: 255-278.

Jackson RA (1995) Clarifying the relationship between education and turnout. American Politics Research 23(3): 279-299.

Karklins R (1986) Soviet elections revisited: Voter abstention in noncompetitive voting. American Political Science Review 80(2): 449-470.

Kepel G (2000) Jihad. Expansion et declin de l'Islamisme. Paris: Gallimard.

Layachi A and Haireche A (1992) National development and political protest: Islamists in the Maghreb countries. Arab Studies Quarterly 14(Spring-Summer): 69-92.

Levitsky S and Way LA (2010) Why democracy needs a level playing field. Journal of Democracy 21(1): 57-68.

Maghraoui AM (2002) Depoliticization in Morocco. Journal of Democracy 13(4): 24-32.

Munson H Jr (1986) The social base of Islamic militancy in Morocco. Middle East Journal 40(2), 267.

Nachtwey J and Tessler M (1999) Explaining women's support for political Islam: Contributions from feminist theory. In: Tessler M (ed.) Area Studies and Social Science Strategies for Understanding Middle East Politics. Bloomington and Indianapolis, IN: Indiana University Press, pp. 48-69.

NDI (2007) Final report on the Moroccan Legislative Elections, 7 September 2007.

Palmer Harik J (1996). Between Islam and the system: Sources and implications of popular support for Lebanon's Hizballah. Journal of Conflict Resolution 40(1): 41-67.

Pellicer M and Wegner E (2009) The Moroccan party of justice and development in local government: Do Islamists govern differently? EUI RSCAS, 2009/53.

REMALD (2003) Tout sur le scrutin du 27 septembre 2002 pour l'élection des membres de la chambre des représentants. Rabat: REMALD.

Robbins MDH (2009) What Accounts for Popular Support for Islamist Parties in the Arab World? Evidence from the Arab Barometer. APSA Annual Meeting, Toronto.

Roussillon A (1991) Entre al-Jihad et al-Rayyan: Phénoménologie de l'islamisme égyptien. In: CEDEJ (ed.) Dossiers du CEDEJ. Etudes Politiques du Monde Arabe. Cairo: CEDEJ, pp. 279-306. 
Roy O (1992) L'échec de l'islam politique. Paris: Le Seuil.

Santucci J (2001) Les partis politiques marocains à l'épreuve du pouvoir. Analyse diachronique et socio-politique d'un pluralisme sous contrôle. REMALD Collections Manuels Et Travaux Universitaires (24).

Santucci J (2005) Les dilemmes du fait partisan dans un contexte autoritaire: réflexions sur le multipartisme marocain. ECPR Joint Sessions, Granada.

Shahin EE (1997) Political Ascent: Contemporary Islamic Movements in North Africa. Boulder, CO: Westview Press.

Sondheimer R and Green DP (2010) Using experiments to estimate the effects of education on voter turnout. American Journal of Political Science 54(1): 174-189.

Storm L (2008) Election Note: Morocco. Electoral Studies 27(2): 359-364.

Storm L (2007) Democratization in Morocco: The Political Elite and Struggles for Power in the Post-Independence State. New York: Routledge.

Taylor-Robinson MM (2006) The difficult road from caudillismo to democracy: The impact of clientelism in Honduras. In: Helmke G and Levitsky S (eds) Informal Institutions and Democracy Lessons from Latin America. Baltimore, MD: Johns Hopkins University Press, pp. 106-124.

Tessler M (1997) The origins of popular support for Islamist movements. A political economy analysis. In: Entelis JP (ed.) Islam, Democracy and the State in North Africa. Bloomington and Indianapolis, IN: Indiana University Press, pp. 93-126.

Tlemcani R (2007) Electoral authoritarianism. Al Ahram Weekly, 24-30 May.

Toth J (2003) Islamism in southern Egypt: A case study of a radical religious movement. International Journal of Middle East Studies 35: 547-572.

Tozy M (1999a) Monarchie et Islam Politique au Maroc. Paris: Presses de Sciences Po.

Tozy M (1999b) Réformes Politiques et Transition Démocratique. Monde Arabe Maghreb-Machrek, 164(avril-juin): $67-84$.

Van de Walle N (2007) Meet the new boss, same as the old boss? The evolution of political clientelism in Africa. In: Kitschelt $\mathrm{H}$ and Wilkinson SI (eds) Patrons, Clients, and Policies: Patterns of Democratic Accountability and Political Competition. Cambridge: Cambridge University Press, pp. $50-67$.

Wegner E (2007) Islamist inclusion and regime persistence: The Moroccan win-win situation. In: Schlumberger O (ed.) Debating Arab Authoritarianism: Dynamics and Durability in Nondemocratic Regimes. Stanford, CA: Stanford University Press, pp. 75-90.
Wegner E (2011) Islamist Opposition in Authoritarian Regimes: The Moroccan Party of Justice and Development. Syracuse, NY: Syracuse University Press.

Wegner E and Pellicer M (2009) Islamist moderation without democratization: The coming of age of the Moroccan Party of Justice and Development? Democratization 16(1): 157-175.

Wegner E and Pellicer M (2010) Hitting the glass ceiling: The trajectory of the Moroccan Party of Justice and Development. Islamist Mass Movements, External Actors and Political Change in the Arab World. Research Report published by International Idea, Centro Studi di Politica Internazionale, and Istituto Affari Internazionali, Italy, pp. 23-50.

Wickham CR (2002) Mobilizing Islam. Religion, Activism, and Political Change in Egypt. New York: Columbia University Press.

Wiktorowicz Q (ed.) (2004) Islamic Activism: A Social Movement Theory Approach. Bloomington, IN: Indiana University Press.

Willis MJ (1999) Between alternance and the Makhzen: AtTawhid wa Al-Islah's entry into Moroccan politics. Journal of North African Studies 4(3): 45-80.

Willis MJ (2002a) Political parties in the Maghrib: Ideology and identification. A suggested typology. Journal of North African Studies 7(3): 1-28.

Willis MJ (2002b) Political parties in the Maghrib: The illusion of significance? Journal of North African Studies 7(2): 1-22.

Willis MJ (2004) Morocco's Islamists and the legislative elections of 2002: The strange case of the party that did not want to win. Mediterranean Politics 9(1): 53-81.

Woltering RA (2002) The roots of Islamist popularity. Third World Quarterly 23(6): 1133-1143.

Yom SL (2009) Jordan: Ten more years of autocracy. Journal of Democracy 20(4): 151-166.

Zeghal M (2005) Les islamistes marocains: le dcfi à la monarchie. Paris: La Découverte.

Zubaida S (1992) Islam, the State and democracy: Contrasting conceptions of society in Egypt. Middle East Report 22(6): $2-10$.

\section{Author biographies}

Miquel Pellicer is Senior Lecturer in the School of Economics at the University of Cape Town. His articles have appeared in, among others, the Journal of Development Economics and Democratization.

Eva Wegner is a Research Fellow in the Southern Africa Labour and Development Research Unit at the University of Cape Town. She is the author of Islamist Opposition in Authoritarian Regimes: The Moroccan Party of Justice and Development (New York: Syracuse University Press, 2011). 